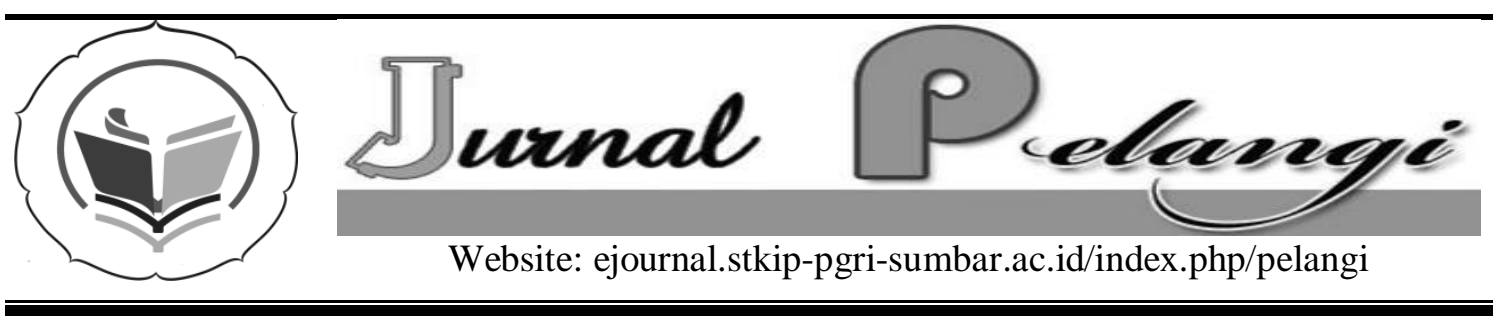

\title{
UPAYA PENINGKATAN HASIL BELAJAR SISWA DENGAN PENGGUNAAN MEDIA FLASH CARD PADA MATA PELAJARAN PENDIDIKAN AGAMA ISLAM
}

Yatinel

SMPN 1 Mungka Lima Puluh Kota

yatinel_spdi@yahoo.com

INFO ARTIKEL

Diterima:

7 Agustus 2016

Direview:

26 September 2016

Disetujui:

28 Desember 2016

\section{Kata Kunci:}

Media flascard, Hasil

Pembelajaran, dan

Pendidikan Agama

\section{Keywords:}

Media flascard, Learning Outcomes, and Religious Education

\begin{abstract}
Abstrak
Pembelajaran Iman Kepada Hari Akhir dengan media Flash Card yang dilakukan dalam tindakan kelas terbukti dapat meningkatkan hasil belajar Pendidikan Agama Islam. Kemampuan peserta didik setelah dilakukan tindakan mengalami peningkatan hasil belajar yang sangat signifikan, hal ini dibuktikan dari hasil belajar setiap siklus mengalami persentase ketuntasan yang terus meningkat, yaitu pada siklus I persentase ketuntasan belajar peserta didik 50\% dan 70,8\%, siklus II mengalami peningkatan menjadi 100\%,. Penggunaan strategi dan media Flash-Card pada materi ajar di dalam kelas sangat membantu tercapainya hasil belajar yang sanga tbaik. Penggunaan media memicu konsentrasi belajar peserta didik sehingga materidapat dipahami dengan mudah. Penggunaan media (Flash-Card) dalam kelompok dapat membantu kekurangan atau kelemahan peserta didik dalam kelompok belajar, dapat memunculkan interaksi yang positif antara peserta didik, sesama pendidik yang dituangkan dalam ide-ide kreatif dalam belajar, serta komunikasi berjalan dengan efektif.
\end{abstract}

Abstract
Iman Learning To Day Weekend with media Flash Card is
done in a class action is proven to improve learning outcomes
Islamic Education. The ability of learners after the act
dilakukant increased very ignifikan learning outcomes, it is
evident from the learning outcomes of each cycle experiencing
ever-increasing percentage of completeness, that in the first
cycle of students learning completeness percentage of 50\% and
$70.8 \%$, the second cycle increased to 100\% The use of
strategies and media Flash-Card on teaching materials in the
classroom greatly help achieve the learning outcomes dross


tbaik. The use of media concentration triggers learners so materidapat understood easily. The use of media (Flash-Card) in a group can help the shortcomings of students in study groups, can bring a positive interaction between students, fellow educators as outlined in creative ideas in learning, and communication is effective.

\section{PENDAHULUAN}

Aplikasi pembelajaran yang menyesuaikan kecerdasan peserta didik merupakan unsur penting yang harus dikembangkan oleh pendidik agar kegiatan belajar mengajar mencapai target yang diharapkan. Ibarat kertas putih, peserta didik itu pada prinsipnya menerima apapun materi yang diberikan oleh guru, karenanya peran pendidik pada saat penyampaian materi belajar sangat diharapkan secara maksimal.

Konteks pembelajaran, eksistensi pendidik sangat vital untuk menjadi agen perubahan kognitif, afektif dan psikomotorik pada peserta didik mulai dari kondisi belajar yang tidak paham menjadi paham, kondisi tidak baik menjadi baik. Oleh karena itu, sejatinya seorang guru harus mempunyai taktik/metode, strategi agar target yang diharapkan dapat tercapai. Dalam Permendiknas No. 16 Tahun 2007 disebutkan bahwa seorang guru harus " menguasai teori belajar dan prinsipprinsip pembelajaran yang mendidik. Menerapkan berbagai pendekatan, strategi, metode dan teknik pembelajaran yang mendidik secara kreatif dalam mata pelajaran yang diampu", ini menunjukkan dalam periode saat ini konteks pembelajaran yang disampaikan kepada peserta didik harus menyesuaikan kemampuan peserta didik dan menggunakan teknik yang dapat menarik simpati, memiliki variasi, dan berdasarkan teori-teori yang juga banyak dikembangkan oleh para pakar pendidikan. Guru tidak diperkenankan lagi dalam penyampaian materi ajarnya dengan hanya menggunakan metode yang monoton yang dapat membuat peserta didik menjadi jenuh sehingga mereka menjadi malas, bahkan timbul rasa tidak simpati pada pelajaran.

Pendidikan agama sebagai mata pelajaran yang paling penting dalam pembelajaran di kelas membutuhkan peranan guru yang mampu menyajikan materi pembelajaran secara efektif dengan menggunakan metode dan media. Pada kondisi ini seorang guru harus menguasai berbagai media dan metode agar materi pendidikan agama dapat disukai oleh peserta didik dan dapat mengoptimalkan kecerdasan anak didik. Kebanyakan materi pendidikan agama disajikan dalam suasana yang tidak eksploratif seperti metode ceramah yang akhirnya membuat peserta didik jenuh. Seperti pada materi "Meningkatkan keimanan kepada hari Akhir" yang hanya disajikan secara doktrinal dan menggunakan satu metode (ceramah) serta sumber media yang kurang menarik seperti LKS (Lembar Kerja Siswa). Dengan pola pembelajaran seperti ini, maka hasil capaiannya pun menjadi jelek bahkan terkesan materi ini tidak penting. Dengan berbagai strategi dan media pembelajaran yang ada, materi ini dapat dikembangkan dengan menarik, menyenangkan dan membuat siswa terlibat aktif sehingga hasil capaiannya menjadi baik. Proses instruksional yang efektif, menyenangkan merupakan prasyarat kondisi pembelajaran yang ideal, namun untuk mewujudkannya dibutuhkan kiat-kiat yang tepat. Penulis mengidentifikasi permasalahan instruksional pada materi 
Meningkatkan keimanan kepada hari Akhir sehingga daya tarik materi ini dan hasil perolehan belajarnya menjadi rendah, sebagai berikut:

1. Metode pembelajaran yang bersifat indoktrinatif

2. Kurangnya motivasi belajar peserta didik

3. Media pembelajaran yang tidak menarik

4. Kurangnya penguasaan pendidik terhadap Strategi pembelajaran

5. Kurangnya penguasaan terhadap kelas

6. Sarana dan prasarana yang kurang memadai

7. Rendahnya minat peserta didik terhadap materi pendidikan agama Islam

8. Sumber bahan pelajaran yang sedikit

Agar pembahasan tidak meluas, maka penulis membatasi penelitian ini tentang "Penggunaan Media Flash-Card untuk Peningkatan Hasil Belajar Pendidikan Agama Islam Di Kelas Ix.4 Semester I Tp. 2010/2011 SMPN 1 Kec. Mungka Kabupaten Limapuluh Kota Pada materi Meningkatkan keimanan kepada hari Akhir. Berdasarkan pembatasan masalah di atas, maka perumusan masalah yang diambil adalah: Apakah dengan menggunakan strategi Flash-Card dapat meningkatkan hasil belajar materi Meningkatkan keimanan kepada hari Akhir?

\section{METODE PENELITIAN}

Penelitian ini dilaksanakan di SMPN 1 Kec. Mungka pada mata pelajaran Agama Islam di kelas IX.4 Penelitian ini dilakukan melalui dua atau tiga siklus yang bertujuan mengetahui perubahan hasil belajar dari setiap siklus dalam materi Meningkatkan Keimanan Kepada Hari Akhir dengan menggunakan media pembelajaran Flash Card.
Subyek penelitian ini adalah siswa SMPN 1 Kec. Mungka Kab. Limapuluh Kota kelas IX.4 Tahun 2010 - 2011 yang berjumlah 24 peserta didik.

Instrumen yang digunakan dalam penelitian adalah Kompetensi Dasar serta lembar kerja siswa, dan observasi lapangan.Teknik pengumpulan data terdiri dari soal tes, observasi, wawancara, disk usi teman sejawat. Analisis Data hasil tes dibuat rerata dan dianalisis secara deskriptif serta untuk mengetahui prosentase ketuntasannya. Hasil pengamatan peneliti dianalisis secara deskriptif mengenai berbagai kejadian dalam proses pembelajaran. Hasil wawancara dianalisis secara deskriptif.

Penelitian tindakan kelas ini dilakukan dengan dua atau Penelitian tindakan kelas ini dilakukan dengan dua atau tiga siklus yang terdiri dari perencanaan, pelaksanaan tindakan, pengamatan tindakan, refleksi tindakan. Penjelasan tahapan siklus tersebut dapat diuraikan di bawah ini:

\section{Siklus I}

1. Perencanaan:

a. Melakukan analisis kurikulum untuk mengetahui kompetensi dasar dan indicator yang akan disampaikan kepada peserta didik dalam pembelajaran

b. Membuat rencana pelaksanaan pembelajaran (RPP) Peningkatan keimanan Kepada Hari Akhir dengan menggunakan media Flas card

c. Membuat soal evaluasi materi Peningkatan keimanan Kepada Hari Akhir untuk peserta didik

d. Membuat instrument yang digunakan dalam siklus PTK

2. Pelaksanaan

Deskripsi tindakan yang akan dilakukan, prosedur tindakan yang diterapkan sebagai berikut: 
a. Presentasi pelajaran di dalam kelas, guru menyampaikan materi pelajaran sesuai dengan kompetensi dasar yang sudah dibuat. kompetensi dasar pada siklus I ini adalah menceritakan proses kejadian kiamat sugra dan kubra sesuai dengan AlQur'an dan Al-Hadits.. Dalam presentasi guru menggunakan media Flas Card agar peserta didik dapat tertarik dengan pembelajaran tersebut.

b. Guru membagi peserta didik dalam empat kelompok untuk bermain Flas Card yang terdiri dari nama-nama peristiwa yang ada dalam kiamat sugra dan kubra.

c. Soal evaluasi. Setelah pembelajaran selesai peserta didik diberikan soal untuk mengetahui tingkat pengetahuan pembelajaran yang telah dilaksanakan.

3. Observasi/pengamatan tindakan

Observasi dilakukan bersamaan dengan pelaksanaan tindakan. menggunakan instrument yang telah disediakan. Peneliti selain mengajar juga memonitor, memfasilitasi dan mengamati jalannya proses pembelajaran serta mengevaluasi hasil dari tindakannya.

4. Refleksi

Hasil temuan yang diperoleh dari pengamatan dianalisis secara kualitatif, sedangkan data kuantitatif (nilai hasil belajar peserta didik) akan dianalisis secara deskriptif. Hasil tersebut selanjutnya akan digunakan untuk menentukan langkah berikutnya pada siklus kedua dan ketiga.

Penelitian kelas ini berhasil apabila:

a. $90 \%$ dari jumlah peserta didik mencapai nilai hasil belajar tuntas melewati KKM.

b. Peserta didik senang pada pembelajaran Peningkatan keimanan Kepada Hari Akhir dengan penggunaan media Flash Card c. Peserta didik aktif dalam pembelajaran diskusi kelompok dan dapat membantu teman yang lemah dalam memnguasai materi

\section{Siklus II}

1. Perencanaan. Peneliti membuat rencana program pembelajaran berdasarkan hasil refleksi pada siklus pertama

2. Peneliti yang merangkap sebagai guru melaksanakan pembelajaran Peningkatan Keimanan Kepada Hari Akhir berdasarkan rencana pembelajaran hasil refleksi pada siklus pertama.

3. Observasi/pengamatan tindakan

4. Peneliti dan teman sejawat melakukan pengamatan terhadap aktivitas pembelajaran.

5. Refleksi. Peneliti dibantu teman sejawat melakukan refleksi terhadap pelaksanaan siklus kedua dan menyusun rencana untuk siklus ketiga.

\section{HASIL DAN PEMBAHASAN}

Hasil Ketuntasan Belajar Siswa Pada Pra siklus didapat hasil rata-rata nilai Tes 52,5 dan ketuntasan belajar 33,3\%. Ketentuan dapat dilihat pada tabel 1.

Tabel 1. Data hasil belajar siswa

\begin{tabular}{clc}
\hline No & Karakter & Nilai \\
\hline 1. & Jumlah Siswa & 24 \\
2. & Rata-rata Post Tes & 52 \\
3. & Jumlah siswa yang tuntas & 8 \\
4. & Jumlah siswa yang tidak & 16 \\
& tuntas \\
\hline
\end{tabular}

Tabel di atas menunjukkan bahwa dari 24 siswa yang mendapatkan nilai $\geq$ KKM 8 siswa, sedangkan nilai KKM adalah 70. Jadi pembelajaran Pra Siklus dari 24 siswa yang tuntas belajarnya 8 orang. Hasil pengamatan pengelolaan pembelajaran disajikan pada Tabel 2. 
Tabel 2. Hasil pengamatan pengelolaan pembelajaran

\begin{tabular}{|c|c|c|c|}
\hline No & Aspek yang Diamati & Skor & Ket. \\
\hline I & Persiapan & 3 & Cukup baik \\
\hline \multirow[t]{14}{*}{ II } & $\begin{array}{l}\text { Pelaksanaan } \\
\text { A Pendahuluan }\end{array}$ & & \\
\hline & 1. Menyampaikan SK,KD & 4 & baik \\
\hline & 2. Memotivasi siswa & 3 & cukup baik \\
\hline & $\begin{array}{l}\text { 3. Menghubungkan pelajaran sekarang } \\
\text { dengan pelajaran terdahulu }\end{array}$ & 3 & cukup baik \\
\hline & B. Kegiatan inti & & \\
\hline & 1. Menyampaikan materi & 3 & cukup baik \\
\hline & 2. Mengatur siswa dalam kelompok & 3 & cukup baik \\
\hline & 3. Mengawasi kelompok secara bergantian & 3 & cukup baik \\
\hline & 4. Membantu kelompok yang kesulitan & 4 & baik \\
\hline & C. Penutup & & \\
\hline & 1. Memberi kesempatan siswa bertanya & 4 & baik \\
\hline & 2. Memberikan evaluasi & 3 & cukup baik \\
\hline & D. Pengelolaan waktu & 3 & cukup baik \\
\hline & E. Suasana Kelas & & \\
\hline \multirow[t]{2}{*}{ III } & 1. Berpusat pada siswa & 3 & cukup baik \\
\hline & 2. Siswa antusias & 3 & cukup baik \\
\hline IV & 3. Guru antusias & 3 & cukup baik \\
\hline
\end{tabular}

Berdasarkan hasil pengamatan di atas, fase yang mendapatkan skor 3 (cukup baik) adalah persiapan. Hal ini disebabkan karena sebagian siswa kurang mengerti tentang materi yang sedang dipelajari dan sebagian siswa masih ada yang bercanda sehingga terkesan mereka belum siap mengikuti tahap pertama. Sedangkan pada fase pelaksanaan yang terdiri dari pendahuluan, kegiatan inti, dan penutup mendapat rata-rata maksimal 3,5 (cukup baik) hal ini disebabkan karena kurangnya penyajian materi yang mengena pada sasaran dan partisipasi siswa yang kurang dioptimalkan. Pengelolaan waktu mendapat skor 3 (cukup baik) disebabkan kurangnya strategi memanfaatkan waktu secara efktif dalam pembelajaran. Suasana kelas mendapat skor rata-rata 3 (cukup baik) hal ini juga disebabkan kurangnya penguasaan terhadap kelas.

Pada Siklus 1 rata-rata nilai Tes 65 dan ketuntasan belajar $50 \%$. Pada siklus I didapat hasil dengan nilai rata-rata Tes 65 dan ketuntasan $50 \%$.

Tabel 3. Data hasil belajar siswa

\begin{tabular}{clc}
\hline No & Karakter & Nilai \\
\hline 1. & Jumlah Siswa & 24 \\
2. & Rata-rata Post Tes & 65 \\
3. & Jumlah siswa yang & 12 \\
4. & Jumlah siswa yang tidak & 12 \\
& tuntas & \\
\hline
\end{tabular}

Tabel di atas menunjukkan bahwa dari 24 siswa yang mendapatkan nilai $\geq$ KKM 12 siswa, sedangkan nilai KKM adalah 70. Jadi pembelajaran Siklus 1 
dari 24 siswa yang tuntas belajarnya hanya 12 siswa.

Dalam belajar guru masih mendominasi pada metode ceramah, partisipasi siswa dalam keaktifan belajar tidak diperhatikan, guru kurang memperhitungkan waktu dalam proses belajar mengajar, guru tidak fokus pada pembelajaran sehingga siswa menjadi bias memahami materi bahasan. hal ini membuktikan hasil belajar siswa tidak mengalami peningkatan yang signifikan. Hasil rerata tes yang diperoleh siswa hanya $65 \%$ atau hanya 12 siswa yang tuntas.

Dari refleksi pada siklus I pertemuan pertama, maka perlu dilakukan revisi untuk perbaikan pada pertemuan kedua siklus I, yaitu : a) Perlu adanya pelibatan peserta didik secara maksimal dalam proses pembelajaran.

b) Guru hendaknya memperhitungkan waktu dengan baik dalam proses pembelajaran sehingga berjalan dengan efektif dan mengenai sasaran.

c) Guru kurang menjelaskan tentang istilah, arti dan tahapan kiamat sugra dan kubra secara maksimal kepada siswa.

Pada tahap ini guru memberikan tes kepada siswa dalam bentuk tes uraian. Dari hasil kegiatan pembelajaran dan pengamatan tersebut diperoleh data sebagai berikut.

Tabel 4. Data pengelolaan pembelajaran

\begin{tabular}{|c|c|c|c|}
\hline No & Aspek yang Diamati & Skor & Ket. \\
\hline $\mathrm{I}$ & Persiapan & 4 & Baik \\
\hline \multirow[t]{13}{*}{ II } & Pelaksanaan & & \\
\hline & i. Pendahuluan & 4 & baik \\
\hline & 1. Menyampaikan SK,KD & 4 & baik \\
\hline & 2. Memotivasi siswa & & \\
\hline & $\begin{array}{l}\text { 3. Menghubungkanpelajaran } \\
\text { sekarangdenganpelajaran terdahulu }\end{array}$ & 4 & baik \\
\hline & ii. Kegiatan inti & & \\
\hline & 1. Menyampaikan materi & 3 & cukup baik \\
\hline & 2. Mengatur siswa dalam kelompok & 4 & baik \\
\hline & 3. Mengawasi kelompok secara bergantian & 4 & baik \\
\hline & 4. Membantu kelompok yang kesulitan & 4 & baik \\
\hline & iii. Penutup & & \\
\hline & 1. Memberi kesempatan siswa bertanya & 4 & baik \\
\hline & 2. Memberikan evaluasi & 3 & cukup baik \\
\hline III & Pengelolaan waktu & 3 & cukup baik \\
\hline \multirow[t]{4}{*}{ IV } & Suasana Kelas & & \\
\hline & 1. Berpusat pada siswa & 4 & baik \\
\hline & 2. Siswa antusias & 4 & baik \\
\hline & 3. Guru antusias & 3 & cukup baik \\
\hline
\end{tabular}


Berdasarkan hasil pengamatan di atas, fase yang mendapatkan skor 4 (baik) adalah persiapan. Hal ini disebabkan siswa sudah mengerti tentang materi yang sedang dipelajari meskipun sebagian siswa masih ada yang bercanda sehingga terkesan mereka belum siap mengikuti tahap pertama. Sedangkan pada fase pelaksanaan yang terdiri dari pendahuluan 4 (baik), kegiatan inti 3,7 (cukup baik) dan penutup mendapat rata-rata maksimal 3,6 (cukup baik) hal ini disebabkan karena masih kurangnya penyajian materi yang menyentuh pada sasaran dan partisipasi siswa masih belum optimal. Pengelolaan waktu mendapat skor 3 (cukup baik) disebabkan kurangnya strategi memanfaatkan waktu secara efktif dalam pembelajaran. Suasana kelas mendapat skor rata-rata 3,6 (cukup baik) hal ini juga disebabkan kurangnya penguasaan terhadap kelas.

Pada siklus I pertemuan kedua didapat hasil dengan nilai rata-rata Tes 77 dan ketuntasan 70,83 \%. Dan ketentuan dapat dilihat pada Tabel 5.

Tabel 5. Data hasil belajar siswa.

\begin{tabular}{clc}
\hline No & Karakter & Nilai \\
\hline 1. & Jumlah Siswa & 24 \\
2. & Rata-rata Post Tes & 77 \\
3. & Jumlah siswa yang tuntas & 17 \\
4. & Jumlah siswa yang tidak & 7 \\
& tuntas & \\
\hline
\end{tabular}

Tabel di atas menunjukkan bahwa dari 24 siswa yang mendapatkan nilai $\geq$ KKM 17 siswa, sedangkan nilai KKM adalah 70. Jadi pembelajaran Siklus 1 pada pertemuan kedua dari 24 siswa yang tuntas belajarnya hanya 17 siswa.

Dalam belajar guru masih mendominasi pada metode ceramah, partisipasi siswa dalam keaktifan belajar tidak diperhatikan, guru kurang memperhitungkan waktu dalam proses belajar mengajar, guru sudah fokus pada pembelajaran sehingga siswa tidak terlalu bias memahami materi bahasan. hal ini membuktikan hasil belajar siswa belum mengalami peningkatan yang signifikan. Guru masih belum terlihat antusias dalam pembelajaran. Hasil rerata tes yang diperoleh siswa hanya 77 $\%$ atau hanya 17 siswa yang tuntas

Dari refleksi pada siklus I pertemuan kedua, maka perlu dilakukan revisi untuk perbaikan pada siklus II, yaitu :

a. Perlu adanya pelibatan peserta didik secara maksimal dalam proses pembelajaran.

b. Guru hendaknya memperhitungkan waktu dengan baik dalam proses pembelajaran sehingga berjalan dengan efektif dan mengenai sasaran.

c. Guru masih terkesan bias dalam menjelaskan tentang istilah, arti dan tahapan kiamat sugra dan kubra secara maksimal kepada siswa.

d. Guru belum antusias terhadap pembelajaran terutama pada pembelajaran kelompok diskusi

Berdasarkan hasil pengamatan pada Tabel 6, telah terjadi peningkatan yang sangat signifikan. Pada bagian persiapan meningkat menjadi skor 4 (baik). Sedangkan pada fase pelaksanaan yang meliputi pendahuluan, kegiatan inti, penutup meningkat menjaji skor 4 (baik). Pengelolaan waktu meningkat menjdi skor 4 (baik). Hal ini disebabkan karena telah terciptanya kondisi belajar yang konkrit di mana siswa telah berpartisipasi dengan baik pada setiap tahapan. 
Tabel 6. Data pengelolaan pembelajaran

\begin{tabular}{|c|c|c|c|}
\hline No & Aspek yang Diamati & Skor & Ket. \\
\hline $\mathrm{I}$ & Persiapan & 4 & Baik \\
\hline \multirow[t]{13}{*}{ II } & Pelaksanaan & & \\
\hline & A. Pendahuluan & 4 & baik \\
\hline & 1. Menyampaikan SK,KD & 4 & baik \\
\hline & 2. Memotivasi siswa & & \\
\hline & $\begin{array}{l}\text { 3. Menghubungkan pelajaran sekarang dengan } \\
\text { pelajaran terdahulu }\end{array}$ & 4 & baik \\
\hline & B. Kegiatan inti & & \\
\hline & 1. Menyampaikan materi & 4 & baik \\
\hline & 2. Mengatur siswa dalam kelompok & 4 & baik \\
\hline & 3. Mengawasi kelompok secara bergantian & 4 & baik \\
\hline & 4. Membantu kelompok yang kesulitan & 4 & baik \\
\hline & C. Penutup & & \\
\hline & 1. Memberi kesempatan siswa bertanya & 4 & baik \\
\hline & 2.Memberikan evaluasi & 4 & baik \\
\hline III & Pengelolaan waktu & 4 & cukup baik \\
\hline \multirow[t]{4}{*}{ IV } & Suasana Kelas & & \\
\hline & 1. Berpusat pada siswa & 4 & baik \\
\hline & 2. Siswa antusias & 4 & baik \\
\hline & 3. Guru antusias & 4 & cukup baik \\
\hline
\end{tabular}

Pada siklus II didapat hasil dengan nilai rata-rata Tes 89 dan ketuntasan 100 $\%$. Dan ketentuan dapat dilihat pada tabel di bawah ini.

Tabel 7. Data hasil belajar siswa

\begin{tabular}{clc}
\hline No & Karakter & Nilai \\
\hline 1. & Jumlah Siswa & 24 \\
2. & Rata-rata Post Tes & 89 \\
3. & Jumlah siswa yang tuntas & 24 \\
4. & Jumlah siswa yang tidak & - \\
& tuntas \\
\hline
\end{tabular}

Tabel di atas menunjukkan bahwa dari 24 siswa yang mendapatkan nilai $\geq$ KKM 24 siswa, sedangkan nilai KKM adalah 70. Jadi pembelajaran Siklus 2 dari 24 siswa yang tuntas belajarnya 24 siswa.

Dalam belajar Siswa sudah menerapkan belajar yang baik, hal ini dibuktikan dari rata-rata hasil belajar siswa mengalami peningkatan menjadi $89 \%$ dari $77 \%$, hal ini terjadi karena kelemahan-kelemahan pada siklus I sudah dapat diatasi dengan adanya siswa dapat mengatasi problem sendiri dalam kerja kelompok dan tidak tergantung kepada guru.

Tabel 8. Data Hasil Observasi

\begin{tabular}{clcc}
\hline \multirow{2}{*}{ No } & \multicolumn{2}{c}{$\begin{array}{c}\text { Aspek yang } \\
\text { diamati }\end{array}$} & \multicolumn{2}{c}{ Siklus } \\
\cline { 3 - 4 } & \multicolumn{1}{c}{ I } & II & Ket \\
\hline I & Persiapan & 3 & 4 \\
\hline II & Pelaksanaan & & \\
\hline & a. Pendahuluan & 3 & 4 \\
\hline & b. Kegiatan & 3,2 & 4 \\
\hline & c. Penutup & 3,5 & 4 \\
\hline \multirow{2}{*}{ III } & $\begin{array}{l}\text { Pengelolaan } \\
\text { Waktu }\end{array}$ & 3 & 3 \\
\hline IV & Suasana Kelas & 3 & 4 \\
\hline
\end{tabular}


Berdasarkan tabel di atas, menunjukkan bahwa pembelajaran Asmaul Husna dengan menggunakan media visualisasi, musikalisasi, maching card secara umum telah berjalan dengan baik mulai siklus I dan siklus II. Hal ini dapat dilihat dari aktivitas guru yang aktif dalam mengelola pembelajaran. Selain itu, guru juga aktif dalam membimbing siswa dalam kelompok belajar. Jadi, secara keseluruhan kemampuan guru dalam pengelolaan pembelajaran telah mencapai kriteria baik dan menunjukkan keefektifan pengelolaan pembelajaran.

Berdasarkan hasil analisis data penelitian menunjukkan bahwa model Pembelajaran dengan menggunakan media Flash Card dapat meningkatkan ketuntasan belajar siswa. Hal ini dapat dilihat pada Tabel 10.

Tabel 10. Data Hasil Belajar

\begin{tabular}{|c|c|c|c|c|}
\hline \multirow{2}{*}{ No } & \multirow{2}{*}{ Aspek yang diamati } & \multirow{2}{*}{$\begin{array}{l}\text { Pra } \\
\text { pra }\end{array}$} & \multicolumn{2}{|r|}{ Siklus } \\
\hline & & & $\mathrm{I}$ & II \\
\hline 1 & Jumlah siswa & 24 & 24 & 24 \\
\hline 2 & Jumlah siswa yang tuntas $\geq$ SKBM & 8 & $\begin{array}{l}12 \\
17\end{array}$ & 24 \\
\hline 3 & $\begin{array}{l}\text { Jumlah siswa yang tidak tuntas } \leq \\
\text { SKBM }\end{array}$ & 16 & $\begin{array}{c}12 \\
7 \\
\end{array}$ & - \\
\hline 4 & Presentase ketuntasan belajar & 31,33 & $\begin{array}{c}50 \% \\
70,8 \%,\end{array}$ & $100 \%$ \\
\hline
\end{tabular}

Pada Pra siklus terdapat hanya 8 siswa yang tuntas belajarnyadari 24 jumlah siswa. Sedangkan pada siklus I pertemuan pertama terdapat 12 siswa yang tuntas belajarnya dan siswa yang belum tuntas sebanyak 12 siswa, pada siklus I pertemuan kedua terdapat 17 siswa yang tuntas belajarnya dan siswa yang belum tuntas sebanyak 7 siswa. Pada siklus II semua siswa telah tuntas belajarnya.

Dari hasil wawancara dalam pembelajaran Meningkatkan keimanan kepada Hari Akhir ini didapat informasi dari perwakilan siswa yang terdiri dari yang mendapatkan nilai terendah, sedang dan tertinggi.

Pengumpulan data dilakukan secara menyeluruh mulai dari data observasi guru pada pembelajaran, dokumentasi, wawancara kepada peserta didik, serta hasil belajar peserta didik pada tes I, II.

Temuan-temuan yang didapat dalam penelitian ini dibahas dengan teman sejawat sebagai upaya penguatan dari penelitian. Agar mendapat hasil yang maksimal dalam proses pembelajaran, PTK ini dikendalikan dengan langkahlangkah pembelajaran melalui rencana pembelajaran terlebih dahulu.

Pembelajaran materi pendidikan Agama Islam dengan menggunakan media pembelajaran terutama pada pembahasan "Meningkatkan Keimanan kepada Hari Akhir" memberikan hasil positif kepada peserta didik. Materi yang cukup rumit untuk peserta didik ini karena kompetensi yang diharuskan adalah meningkatkan keimanan kepada hari Akhir. Dalam kehidupan sehari-hari, menjadi ringan dipahami karena eksplorasi pembelajaran dengan melibatkan banyak unsur dalam indra peserta didik. Sehingga tanpa disadari peserta didik dapat menguasai materi tersebut.

Kelemahan menghafal peserta didik pada materi Iman Kepada Hari Akhir 
dapat diatasi akibat partisipasi aktif dalam kerja kelompok mereka. Interaksi dengan pendidik yang baik dalam pembelajaran menyebabkan mereka dapat belajar secara optimal.

Problem belajar dapat teratasi dengan keterlibatan pendidik dalam memberikan arahan kepada peserta didik utamanya dalam kerja kelompok. Pembelajaran yang terjadi tidak lagi bersifat kompetitif tetapi menjadi kolaboratif yang dapat menciptakan keberhasilan bukan secara individu tetapi keberhasilan secara bersama-sama.

Kemajuan belajar pada setiap siklus pembelajaran dapat memberikan hasil yang berarti bagi kemampuan peserta didik baik kemampuan kognitif, afektif, psikomotorik. Dalam kemampuan kognitif peserta didik pada pembelajaran Iman kepada Hari Akhir terdapat peningkatan yang sangat signifikan pada setiap siklusnya. Pada siklus I peserta didik yang tuntas $50 \%$ dan 70,8\%, pada siklus II peserta didik yang tuntas '100 \%,. Dengan demikian dapat disimpulkan bahwa peserta didik dapat mengalami peningkatan hasil belajar Iman Kepada Hari akhir yang sangat signifikan setelah dilakukan tindakan kelas selama dua siklus dengan menggunakan strategi dan media FlashCard.

\section{PENUTUP}

Pembelajaran Iman Kepada Hari Akhir dengan media Flash Card yang dilakukan dalam tindakan kelas terbukti dapat meningkatkan hasil belajar Pendidikan Agama Islam. Kemampuan peserta didik setelah dilakukan tindakan mengalami peningkatan hasil belajar yang sangat signifikan, hal ini dibuktikan dari hasil belajar setiap siklus mengalami prosentase ketuntasan yang terus meningkat, yaitu pada siklus I prosentase ketuntasan belajar peserta didik $50 \%$ dan $70,8 \%$, siklus II mengalami peningkatan menjadi $100 \%$, Penggunaan strategi dan media FlashCard pada materi ajar di dalam kelas sangat membantu tercapainya hasil belajar yang sanga tbaik. Penggunaan media memicu konsentrasi belajar peserta didik sehingga materidapat dipahami dengan mudah. Penggunaan media (Flash-Card) dalam kelompok dapat membantu kekurangan atau kelemahan peserta didik dalam kelompok belajar, dapat memunculkan interaksi yang positif antara peserta didik, sesama pendidik yang dituangkan dalam ide-ide kreatif dalam belajar, serta komunikasi berjalan dengan efektif.

\section{UCAPAN TERIMA KASIH}

Terbitnya tulisan ini tidak terlepas dari bantuan berbagai pihak, untuk itu penulis ucapkan terima kasih yang sebesar-besarnya kepada Pihak STKIP PGRI Sumatera Barat khususnya pengelola jurnal Pelangi yang telah memberikan kesempatan kepada penulis untuk menulis di Jurnal Pelangi. Selanjutnya penulis juga berterima kasih kepada para penyumbang sumber insirasi yang telah memberikan inspirasi bagi penulis untuk mengutip atau menggunakan tulisannya sebagai bahan referensi.

\section{DAFTAR RUJUKAN}

Arikunto, Suharsimi, et.al. 2009. Penelitian Tindakan Kelas. Jakarta: Bumi Aksara.

Atmowidjoyo, $\quad$ Sutardjo. 2009. Landasan Kependidikan. Jakarta: UIJ.

Chatib, Munif. 2011. Gurunya Manusia. Bandung: kaifa. 
Dananjaya, Utomo. 2010. Media Pembelajaran Aktif. Bandung: Nuansa.

Faturrahman, Pupuh, et.al. 2009. Strategi Belajar Mengajar. Bandung: Refika Aditama.

Kartanegara, Mulyadi. 006.

Reaktualisasi Tradisi Ilmiah

Islam. Jakarta:Baitul Islam.

Koesoema, Doni A. 2007. Pendidikan

Karakter (Strategi Mendidik Anak di Zaman Global). Jakarta: Grasindo.

Kusumah, Wijaya, et,al. 2010. Mengenal Penelitian Tindakan kelas. Jakarta: Indeks.

L' Duanne, Johnson. 2009. Pengajaran Yang Kreatif dan Menarik. PT. Mancana Jaya Gemilang.

Majid, Abdul. 2008. Perencanaan Pembelajaran. Bandung: RosdaKarya,.

Nasution. 2008. Teknologi Pendidikan. Jakarta: Bumi Aksara.

Setiabudhi, Tony, et,al. 2003. Anak Unggul Berotak Prima. Jakarta: Gramedia.
Sukarno. 2009. Penelitian Tindakan Kelas (Prinsip-prinsip Dasar, Konsep dan Implementasinya). Surakarta: Media Perkasa.

Sumiati, Asna. 2007. Metode Pembelajaran. Bandung: Wacana Prima.

Susetyo, Berry. 2005. Politik Pendidikan Penguasa. Yogyakarta: LKIS.

Trianto. 2007. Model-model Pembelajaran Inovatif Berorientasi Konstruktiristik. Jakarta: Prestasi Pustaka Publisher.

Uno, Hamzah B. 2009. Model Pembelajaran Menciptakan Proses Belajar Mengajar yang Kreatif dan Efektif. Jakarta: Bumi Aksara.

Wibowo, Basuki, et. al. 2008. Bunga rampai Kajian Pendidikan Nasional. Jakarta: BP-FT.

Ya'qub, Ali Mustafa. 2000. Sejarah dan Metode Dakwah Nabi saw. Jakarta: Pustaka Firdaus.

Napitupulu, et.al.26 Mei, 2010. Teknologi Ubah Cara Belajar. kompas,hlm. 11. 